\title{
PROPERTY TAX IN THE REGIONS OF THE CZECH REPUBLIC
}

\author{
Jana Janoušková, Šárka Sobotovičová
}

\section{Introduction}

The issue of fiscal decentralization in the context of the fiscal autonomy of local selfgovernments is still current. The Czech Republic is among the countries with lower tax autonomy (Blöchliger \& Pinero Campos, 2011; OECD, 2016; Sedmihradská, 2015). The revenue from assigned taxes and from subsidy programs makes up decisive share in municipal budgets. The state specifies the percentage of revenue for this type of tax that belongs to a specific part of the budget system (in the case of the Czech Republic i.e. regions and municipalities). In terms of a flexible response, this method of funding does not give municipalities much possibility, as they may influence the amount of such revenues only through their interventions to a very small extent. In addition, non-guaranteed access to subsidies brings a certain uncertainty and hinders the possibility of revenue prediction for the nearest period (Janoušková \& Sobotovičová, 2016a).

One of the stable revenues of municipalities is a tax on immovable property (formerly real estate tax) flowing into municipal budgets in most EU countries. Thus, the principle of benefit (Keith \& McCluskey, 2004; Mrkývka, 2003) and the principle of subsidiarity are fulfilled, where decision-making and responsibility in public affairs takes place at the lowest level of public administration being closest to the citizens. Municipalities have the option to adjust the structural elements of the tax, and they can then manage their revenues. These taxes are revenue stable (Birch \& Sunderman, 2013; Bečica, 2014), and they do not have a distortion effect on work, as well as they do not hamper the economic activity to such an extent as the income taxes, which directly cut back the yield from a work activity. They should lead the owners of immovable property to a more rational and more effective property management. However, political representation often shies away from these tax increases in the context of the potential number of votes (Bird, 2010).

The tax on immovable property is one of the basic tools of fiscal decentralization. Fiscal decentralization in theory is associated in particular with the efficiency of allocation of funds to secure public goods within the public sector. It is related to the discussion of the strengthening of the role of local selfgovernments, especially, the powers of decisionmaking and responsibilities of municipalities in the economic field. Decentralization allows for a greater public involvement in decisionmaking and brings even greater transparency and efficiency in the use of financial resources (Tiebout, 1956; Bish \& Kirk, 1974). Local selfgovernments can use the tax on immovable property to influence the revenues of their own budgets in favour of improving the quality of life in the place of tax collection (Haider-Markel, 2014; Marková, 2007; Bird, 2011; Roubínek et. al., 2015).

In the context of the economic transformation in Central and Eastern Europe in the 1990s, the extreme centralization has been overcome, moreover the ways of the gradual decentralization and strengthening of the autonomy of municipalities are searched for, which should lead to the efficiency of public services (Tanzi, 1991). Authors, such as Smith et al. (2011) are investigating the local perception of progress towards fiscal decentralization in the context of the transformation of the Czech economy in the 1990s. Transitive economies (Bryson, 2010) confronted the problem of the reconstructing of the self-government, the definition of competencies in selecting the sources of their financing or by providing for their self-sufficiency in acquiring revenues. In the context of the taxation of immovable 
property, it is possible to keep track of more different approaches and empirical studies. Property valuation for purposes of determining the tax base of the real estate is often a hot topic (Horne \& Felsenstein, 2010; Presbitero, Sacchi, \& Zazzaro, 2014). Moreover, the Czech Republic is criticized for its unit approach in the determination of the tax base and a lack of coherence on the fair value of the real estate (OECD, 2010; OECD, 2011; European Commission, 2015). The Czech Republic is also recommended an increase in this tax revenue, as it accounts for a small proportion of the total tax revenues in comparison with other EU countries. Coombs, Sarafoglou and Crosby (2012) dealt with the possibility of using the taxation of immovable property in connection with a potential increase in the revenue for municipal budgets.

\section{Taxation of Immovable Property in the Czech Republic}

In the Czech Republic, the tax revenue on immovable property flows into the budget of the municipality on whose territory the immovable property is located. Tax rates, are set by law and their amount is the same for all municipalities. A municipality may affect the amount of the revenue, in particular by means of the coefficients, which it determines generally by a binding public notice. This is a corrective coefficient based on the number of inhabitants, the municipal and local coefficient (Janoušková \& Sobotovičová, 2016b).

The corrective coefficient depends on the number of inhabitants in the municipality. The municipality has the possibility to affect the amount of the coefficient by reducing it for individual parts of the municipality by one to three categories or increase it by one category. The coefficient is applied to residential buildings and their appurtenances and units. The corrective coefficient is also applied to construction sites and due to modifications, the amount of corrective coefficients for buildings and land may vary. The municipality may set the municipal coefficient at 1.5 and burden essentially only non-residents of the municipality. Indeed, it applies to buildings used for family recreation, garages and buildings for business. The advantage of this coefficient is that it does not burden buildings for permanent housing, and vice versa, the disadvantage is that a municipality cannot influence its amount. The municipality can set the local coefficient at two, three, four and five. The entire calculated tax obligation is multiplied by this coefficient, except for some land (arable land, grassland).

Tax revenues on immovable property have had a growing trend since 1993. This trend is influenced by many factors, for example, since 2001 , by the improvement of the state of registration in the Land Registry and

\section{Fig. 1: The development of the tax revenue from immovable property in the Czech Republic}

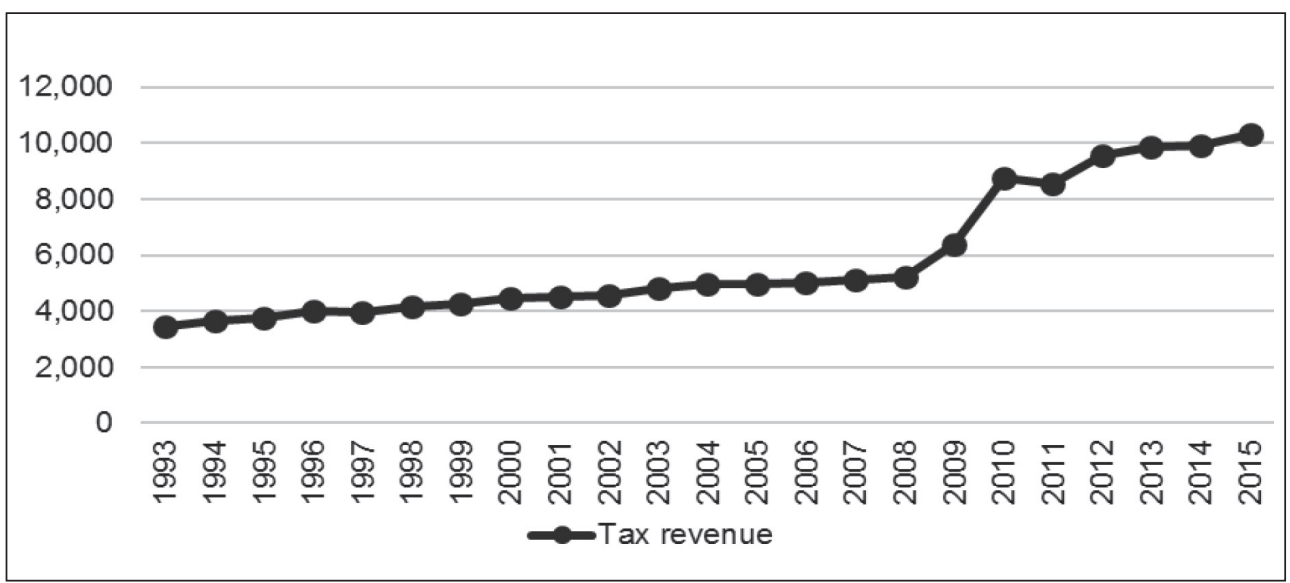


transparency of ownership relations and by streamlining control and search operations of local financial authorities. The most significant factor, however, are legislative changes. In 2009, the exemption from completed constructions of residential houses and buildings, where insulation was carried out, was abolished, along with introducing the possibility of setting the local coefficient. Another major change that affected the tax yield on immovable property was the increase in tax rates from 2010 onwards. The reduction of the tax revenues in 2011 occurred partly as a consequence of the increase in the volume of arrears, but also due to additional reductions and subsequent tax refunds for the previous tax year as a result of court decisions. The gradual precision of legal norms had also a positive impact on increasing tax yields on immovable property.

\section{Position of the Regions of the Czech Republic in the Context of Tax Yields on Immovable Property} In the Czech Republic there are fourteen local self-governing units, these are 13 regions and the capital Prague, not an independent region, however, has the same powers as a region. There are many geographic, demographic and socio-economic disparities among individual regions.

As seen from the graph (Fig. 2), in terms of the area and population the Central Bohemian
Region is the largest. The lowest population is in the Karlovy Vary Region, which is also the second smallest by area. Large differences between regions are also in population density, which is the highest in the Moravian-Silesian Region (224 inhabitants per $\mathrm{m}^{2}$ ). On the contrary, the lowest density of population is in the South Bohemian Region, which is the second largest by area. The Capital City of Prague shows a specific position among the regions, which has a small area but a large number of inhabitants $(12 \%$ of the total population in the Czech Republic) and thanks to it, it is a place with the highest population density, which is 2,555 people per $\mathrm{m}^{2}$.

A tax imposed in individual regions (Fig. 3) shows a similar trend as tax revenues on immovable property in Fig. 1. The tax imposed is growing with a significant increase between 2009 and 2010, in connection with legislative changes in those years. The highest amounts of the tax imposed are in the Central Bohemian Region, the South Moravian Region and Moravian-Silesian Region, while the lowest are in the Karlovy Vary Region.

As it can be seen from Tab. 1 the comparison of the regions in terms of taxes on immovable property is significantly different when compared by area and population. The highest amount of taxes per 1 ha is in Prague and in the Moravian-Silesian Region and in the Usti Region. These are the industrial

\section{Fig. 2: The size of local self-governing units in terms of the area and population (in \%)}

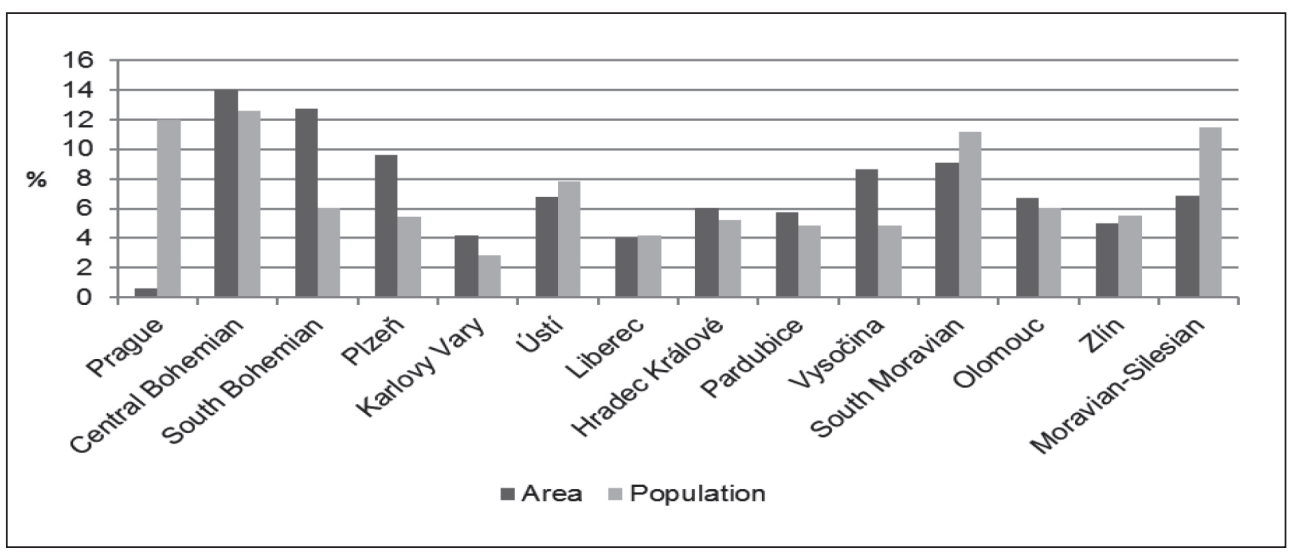




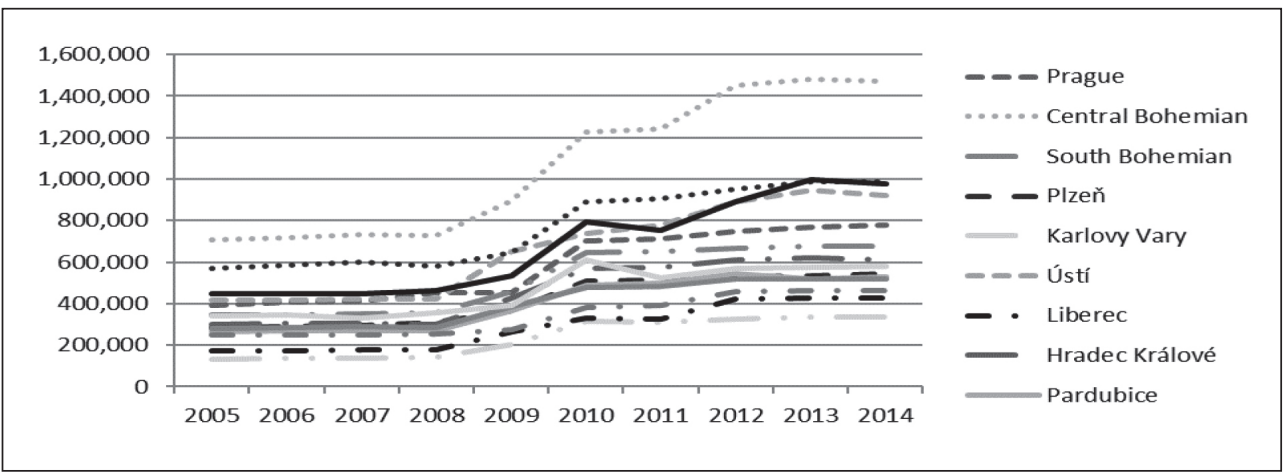

Source: Tax administration (2015), own processing

\begin{tabular}{|c|c|c|c|}
\hline $\begin{array}{l}\text { The co } \\
\text { (in tho }\end{array}$ & $\begin{array}{l}\text { f regions in terms } \\
\text { K) }\end{array}$ & of the tax imposed in & \\
\hline & Tax imposed & Tax imposed per 1 ha & $\begin{array}{c}\text { Tax imposed per } 1 \\
\text { inhabitant }\end{array}$ \\
\hline Prague & 779,024 & 15,701 & 623 \\
\hline Central Bohemian & $1,473,171$ & 1,337 & 1,125 \\
\hline South Bohemian & 678,594 & 675 & 1,065 \\
\hline Plzeň & 542,278 & 717 & 945 \\
\hline Karlovy Vary & 338,402 & 1,021 & 1,128 \\
\hline Ústí & 923,401 & 1,731 & 1,120 \\
\hline Liberec & 428,501 & 1,355 & 977 \\
\hline Hradec Králové & 610,450 & 1,283 & 1,106 \\
\hline Pardubice & 527,293 & 1,167 & 1,022 \\
\hline Vysočina & 520,384 & 766 & 1,020 \\
\hline South Moravian & 986,112 & 1,371 & 842 \\
\hline Olomouc & 579,394 & 1,100 & 911 \\
\hline Moravian-Silesian & 977,706 & 1,802 & 802 \\
\hline Zlín & 463,443 & 1,169 & 791 \\
\hline
\end{tabular}

Source: Czech Statistical Office (2016), Tax administration (2015), own calculation

regions. According to the amount of taxes per 1 inhabitant the highest amount of taxes is in the Central Bohemian Region, the Karlovy Vary Region and the Usti Region. In contrast, absolutely the lowest property tax per capita is in Prague. It is the largest city in the Czech Republic, which has namely the highest corrective coefficient according to population; on the other hand, Prague has not introduced the local coefficient.

\section{Goal and Methods}

The primary objective of the research is to determine the use of legislative instruments, 
leading to an increase in tax revenues from immovable property in the regions of the Czech Republic. Access of municipalities to the increase in the tax revenues on immovable property is then studied through coefficients within the Moravian-Silesian Region. Using a questionnaire survey the use of individual coefficients and reasons, leading municipalities to their implementation, modification or cancellation are examined. This research closely follows up on the research of the use of local coefficients, which was carried out in 2014 and 2015.

In the article, there is also a description of the immovable property tax development in the Czech Republic based on time series of the tax imposed in response to legislative changes. The dynamics of the time series was investigated using a growth rate that was in the year $t$ calculated according to formula (1):

$$
k_{t}=\frac{y_{t}}{y_{t-1}}, t=2,3, \ldots, n
$$

where $y_{t}$ is the value of the immovable property of the tax imposed in the year $t, y_{t-1}$ is the value of the immovable property tax imposed in the year $t-1$.

The tax imposed represents the amount of tax as reported in tax returns and yield $(\mathrm{Y})$ is calculated according to formula (2):

$$
Y=\frac{T R}{T I} * 100
$$

where $T R$ is tax revenue, $T I$ is tax imposed.

By using the chi-square test it was verified whether the municipality location in the district influenced its decision on assessing or modifying coefficients.

A contingency table was created, based on observed and expected frequencies, which were calculated according to the following formula (3):

$$
E_{i j}=\frac{n_{i}}{n} \cdot \frac{n_{j}}{n} \cdot n=\frac{n_{i} n_{j}}{n}
$$

where $n_{i}$ is the sum of individual lines, $n_{j}$ is the sum of individual columns in the contingency table, $n$ is the sum of all observed frequencies.

The test criterion was calculated using the formula (4):

$$
T=\sum_{i=1}^{2} \sum_{j=1}^{s} \frac{\left(O_{i j}-E_{i j}\right)^{2}}{E_{i j}}
$$

where $s$ means the number of categories of a monitored variable.

Critical value $K=\chi_{\alpha}(s-1)$ of chi-squared distribution with a degree of freedom $\mathrm{df}=\mathrm{s}-1$ was calculated using Excel and the function CHIINV ( $\alpha$; df) for the given level of significance a 0.05 (Ramík \& Perzina, 2014). To verify the accuracy, significance ( $p$-value) was calculated and was compared with the chosen significance level $(\alpha=0.05)$. The function CHIDIST (T; df) was used for the $p$-value calculation.

Methodically, the research relies on the evaluation of secondary statistical data of the Czech Statistical Office and the General Financial Directorate of the Czech Republic. The paper used the results of primary research focused on the application of the coefficients by municipalities of the Moravian-Silesian Region, which was implemented in 2016, by a questionnaire through personal interviews, email or telephone.

\section{Results and Discussion}

As it is evident from the data in Tab. 2, the growth rate in 2009 in all local self-governing units is greater than one, as a result of the possibility of introducing a local coefficient, which could be just used for the first time in this year. 389 municipalities introduced the local coefficient, which accounts for $6.22 \%$ of the total number of municipalities in the Czech Republic. In 2010, the growth rate is again high and it is even higher than 1.5 in some regions and in Prague. This fact is influenced by doubling the basic rate of tax on all land, buildings and units (excluding agricultural land and buildings for other business activities). Increasing tax rates led some municipalities to cancel the local coefficient (it was the case of about 189 municipalities), other municipalities introduced it newly in 2010 (83 municipalities). Given that the various local self-governing units have different areas, types of land and buildings, the impact of the increase in tax rates is different, too.

As already mentioned in the beginning, the structure of financial resources of municipalities is diverse and consists of tax and non-tax revenues. Tax revenues are critical for municipal budgets and taxes are made up of shared and 
Tab. 2:

The development of the coefficient growth of the tax imposed

\begin{tabular}{l|c|c|c|c|c|c|c|c|c} 
& $\mathbf{2 0 0 6}$ & $\mathbf{2 0 0 7}$ & $\mathbf{2 0 0 8}$ & $\mathbf{2 0 0 9}$ & $\mathbf{2 0 1 0}$ & $\mathbf{2 0 1 1}$ & $\mathbf{2 0 1 2}$ & $\mathbf{2 0 1 3}$ & $\mathbf{2 0 1 4}$ \\
\hline Prague & 1.04 & 1.01 & 1.09 & 1.01 & 1.54 & 1.02 & 1.05 & 1.02 & 1.02 \\
\hline Central Bohemian & 1.01 & 1.03 & 0.99 & 1.23 & 1.37 & 1.01 & 1.17 & 1.02 & 0.99 \\
\hline South Bohemian & 1.00 & 1.03 & 1.01 & 1.27 & 1.42 & 1.00 & 1.02 & 1.01 & 1.01 \\
\hline Plzeň & 1.01 & 1.02 & 1.05 & 1.18 & 1.38 & 1.01 & 1.03 & 1.01 & 1.01 \\
\hline Karlovy Vary & 1.03 & 0.99 & 1.03 & 1.44 & 1.54 & 0.99 & 1.05 & 1.02 & 1.02 \\
\hline Ústí & 1.00 & 1.01 & 1.01 & 1.53 & 1.13 & 1.05 & 1.15 & 1.06 & 0.98 \\
\hline Liberec & 0.99 & 1.02 & 1.00 & 1.49 & 1.26 & 0.99 & 1.29 & 1.01 & 1.00 \\
\hline Hradec Králové & 1.02 & 1.00 & 0.98 & 1.42 & 1.33 & 1.01 & 1.06 & 1.02 & 0.98 \\
\hline Pardubice & 1.02 & 1.00 & 1.00 & 1.36 & 1.33 & 1.03 & 1.08 & 0.96 & 1.01 \\
\hline Vysočina & 1.01 & 1.01 & 0.99 & 1.35 & 1.24 & 1.01 & 1.07 & 1.00 & 1.00 \\
\hline South Moravian & 1.02 & 1.02 & 0.97 & 1.11 & 1.37 & 1.02 & 1.05 & 1.04 & 1.00 \\
\hline Olomouc & 1.01 & 0.96 & 1.08 & 1.09 & 1.56 & 0.86 & 1.08 & 1.01 & 1.00 \\
\hline Moravian-Silesian & 1.00 & 1.00 & 1.04 & 1.16 & 1.48 & 0.95 & 1.18 & 1.12 & 0.98 \\
\hline Zlín & 1.00 & 1.01 & 1.02 & 1.07 & 1.39 & 1.04 & 1.16 & 1.01 & 1.00 \\
\hline
\end{tabular}

Source: own calculation

\section{Fig. 4: The development of the use and modifications of coefficients by municipalities in individual regions (in \%) in 2015}

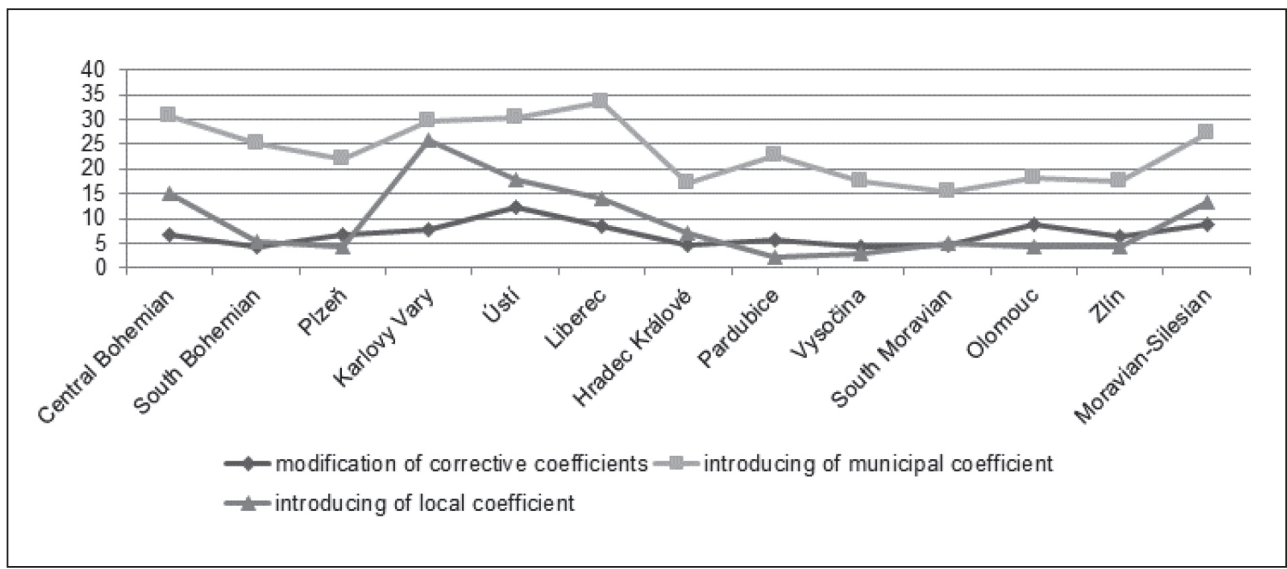

Source: own calculation

assigned taxes. Revenues on shared taxes are transferred to municipal budgets under the Act on budgetary allocation of taxes and the municipality has no possibility to influence their amount.
The assigned tax, i.e. a tax on immovable property in the Czech Republic can respond to the actual costs of the municipality. The amount of tax revenues on immovable property within the local self-governing units is significantly 
influenced by the decision of individual municipalities on introducing or modifying coefficients. The following graph (Fig. 4) specifies the percentage use of coefficients in individual regions. Due to differences in the number of municipalities in the regions, the percentage use was compared.

From Fig. 4, it is clear that the municipal coefficient is most used. This coefficient applies to buildings for family recreation and for buildings used for business. Therefore, a coefficient does not burden the residents of the municipality. In the Central Bohemian Region, the Liberec Region and the Usti Region this possibility is used by more than $30 \%$ of the municipalities. The use of the modification of corrective coefficients is low (in the Czech Republic the average use is $6.4 \%$ ). There are not enormous differences among regions and rather modifications are used to differentiate various parts of the municipality. The modification is most used by municipalities in the Usti Region. The local coefficient can be considered the most effective tool, by which the municipality as a recipient of tax can significantly increase the tax revenue on property on its territory, and it is used by an average of $8.3 \%$, and municipalities in the Karlovy Vary Region use it most. In that region, more than a quarter of municipalities have adopted a similar strategy and some of them have introduced a local coefficient since 2009 and have used it up to the present.

\subsection{The Form of Fiscal Autonomy in the Moravian-Silesian Region}

Subsequent research aims to identify and evaluate the regional context of the activities of municipalities in the Moravian-Silesian Region in connection with influencing tax revenues on immovable property. In the following graph (Fig. 5) the distribution of municipalities in the Moravian-Silesian Region by population is shown. Size groups are determined by population for applying the corrective coefficient for calculating the tax on immovable property.

\section{Fig. 5: The distribution of municipalities in the Moravian-Silesian Region by size groups}

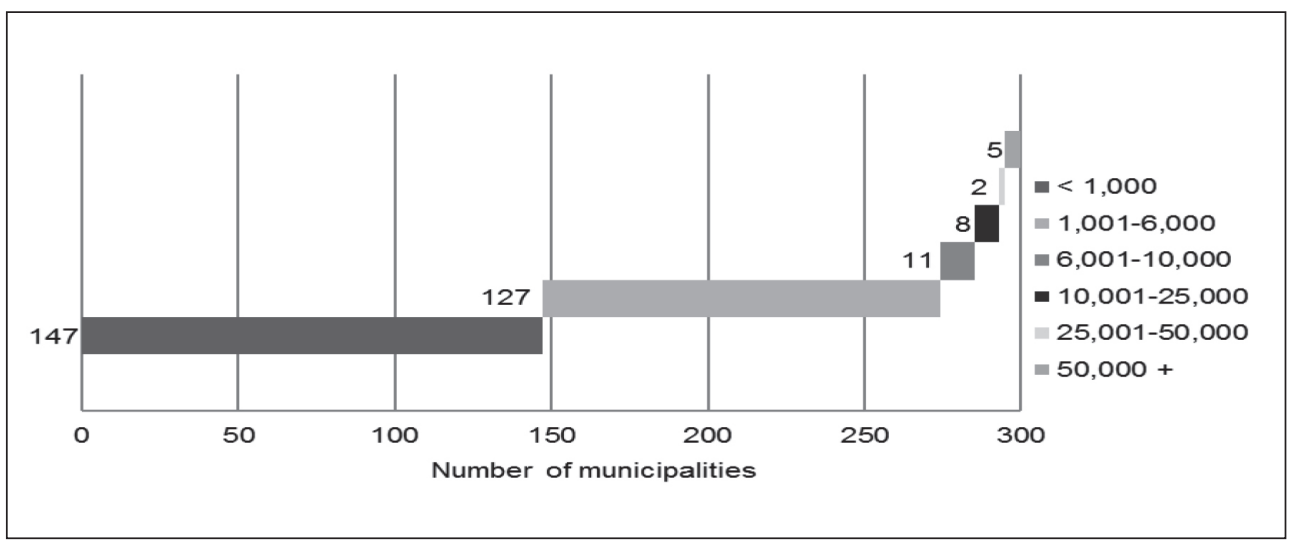

Source: Czech Statistical Office (2016), own calculation

In the Moravian-Silesian Region, there are 300 municipalities. Of these only 109 municipalities (Fig. 6) use the determination or the modification of coefficients for influencing the tax revenues on immovable property. Municipalities may introduce or modify the amount of the three coefficients. Most municipalities use only the modification of just one coefficient. The decrease in the corrective coefficient is used least, and only by 8 municipalities. A combination of introducing the municipal coefficient is inspirational, while reducing corrective coefficients. This fact has been detected only in 5 cases, though. This approach can be observed especially in municipalities that want to provide the required tax yields especially from other entities other than its own citizens. 
Fig. 6: The use of coefficients by municipalities in the Moravian Silesian Region

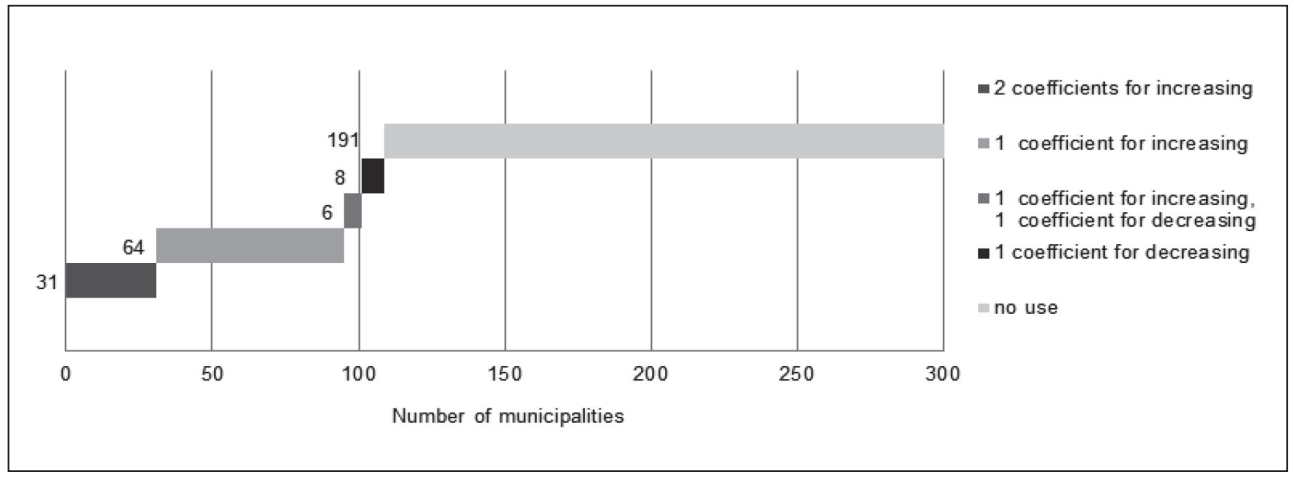

Source: own calculation

\subsection{The Results of Empirical Research and Discussion}

The research is focused on exploring the use of coefficients of the tax on immovable property by individual municipalities and was conducted by questioning. The research instrument involved a questionnaire, which included both closedended and open-ended questions, in which the respondent was not submitted response options, and the respondent answered in his/ her words. The responses were then grouped according to semantic categories.
This is a local research, which focuses on the Moravian-Silesian Region. The region has a total of 300 municipalities, and 250 of them were addressed. 100 questionnaires were placed into processing and the response rate was $40 \%$.

The structure of respondents (municipalities) by size is shown in the following Fig. 7. The graph shows that most respondents are formed by municipalities with a population of 1,001 to 6,000 . The structure of the respondents is influenced by a low response rate of questionnaires in the smallest municipalities with a population of up to 1,000 .

\section{Fig. 7: The structure of respondents by size of the municipality}

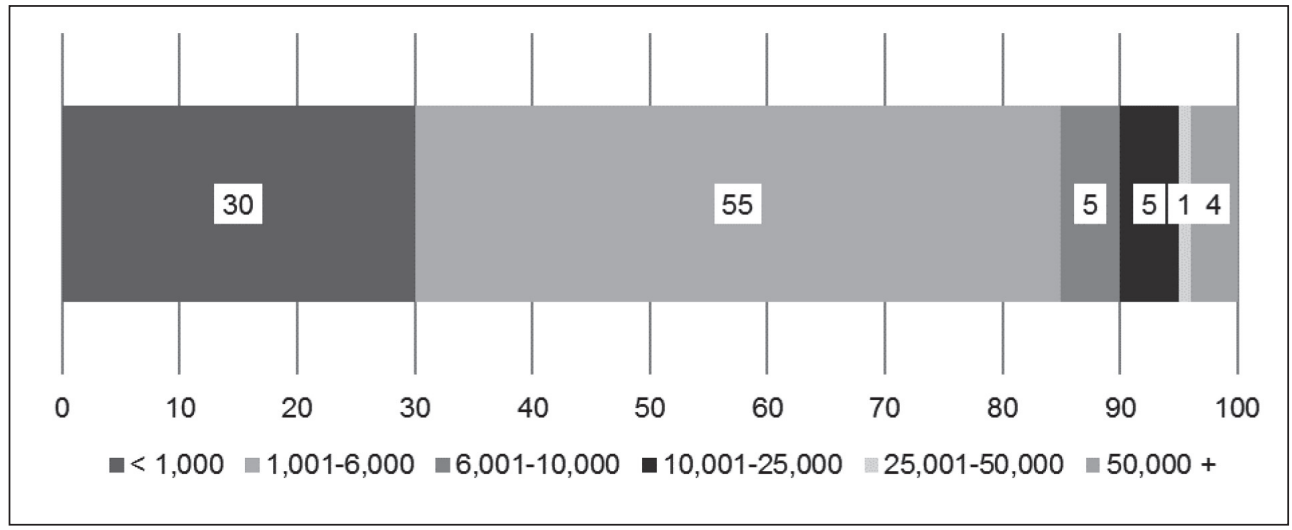




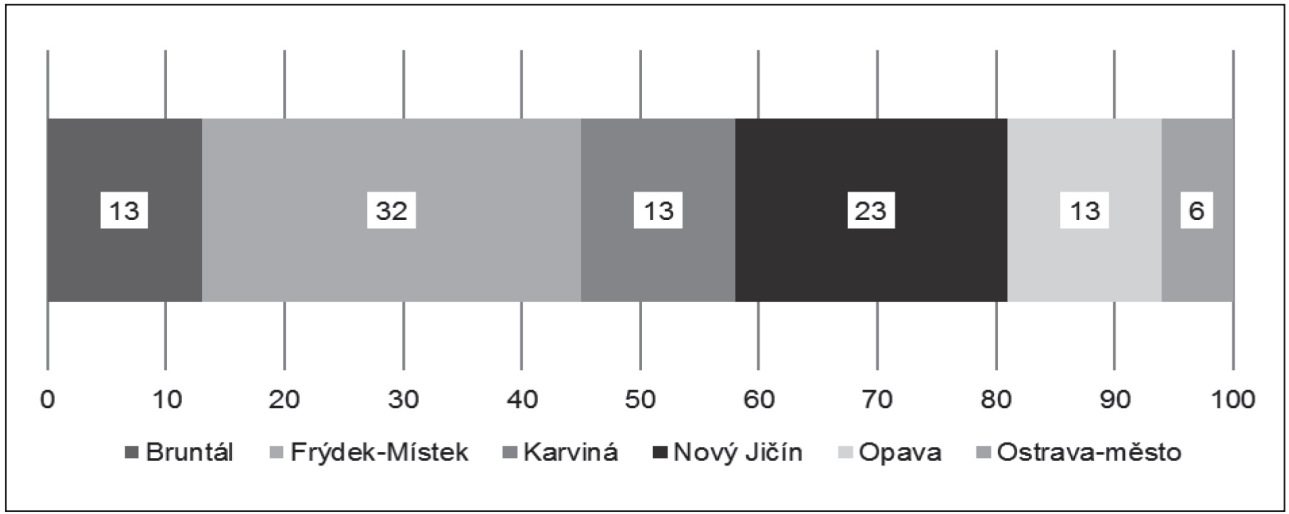

Source: own calculation

The structure of the respondents in terms of districts in the Moravian-Silesian Region is shown in Fig. 8. A small number of respondents in districts with a large number of municipalities is, among others, influenced by a varying size structure of municipalities, where for example in the Bruntál district there are $78 \%$ of municipalities with a population up to 1,000 and, for instance, in the Karvina district there is not any such a small municipality.

\subsection{Motivation for Introducing the Coefficients by the Municipalities of the Moravian-Silesian Region}

The reasons which led the municipalities to the introduction of coefficients were determined by using open-ended questions and then were grouped into semantic categories.

As it is evident from Fig. 9 above the most common reason that motivated municipalities to introduce municipal coefficients was to increase

\section{Fig. 9: Motivation for introducing municipal coefficients}

increase the taxation of buildings for family recreation and for business

increase the revenue of the municipality for certain purpose

increase the revenue of the municipality increase the taxation of buildings for family recreation

increase the taxation of buildings for business

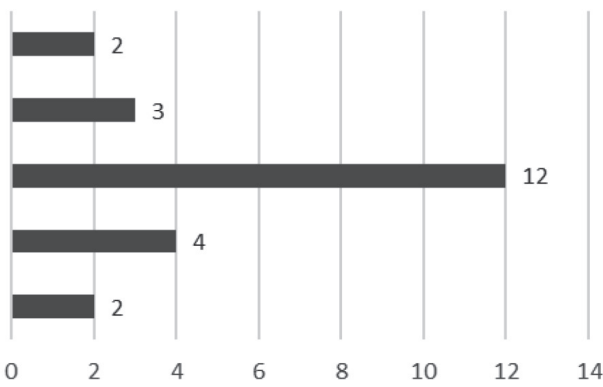

- Number of respondents 
the revenue of the municipality. By determining municipal coefficients some municipalities wanted to increase the taxation of buildings for family recreation or for business. The increase in this tax liability thus does affect the population of the given municipality. In determining this coefficient, municipalities cannot choose its amount, but they can specify to which types of buildings (except buildings for permanent housing) the coefficient will apply. There were also reasons from which an insufficient orientation in the field of the tax on immovable property could be inferred, for instance, the coefficient was set by another mayor then they do not know the reasons or the coefficient was set at the request of tax authorities. If the municipalities stated that the reason for setting the coefficient was to increase the revenue of the municipality for a specified purpose, the most often mentioned were: the beautification of municipal areas, covering the costs of the cleanliness of the municipality, covering the costs of sewerage, flood protection measurements, health, sport and culture. The municipal coefficient was introduced in 28 municipalities surveyed.

Corrective coefficients are determined by law, and as mentioned above, they can be modified differently for land and buildings through their increase or decrease. The corrective coefficient for land was modified by 18 municipalities and by 17 municipalities for buildings.

When modifying corrective coefficients for land a different objective is usually pursued than

\section{Fig. 10: Motivation for modifying corrective coefficients for land}

decrease coefficient for the reason of supporting the new building in the selected location

increase the coefficient as an incentive to shorten the building period

decrease coefficient for separated and isolated parts of the municipality

differentiate the various parts of the municipality

increase the revenue of the municipality

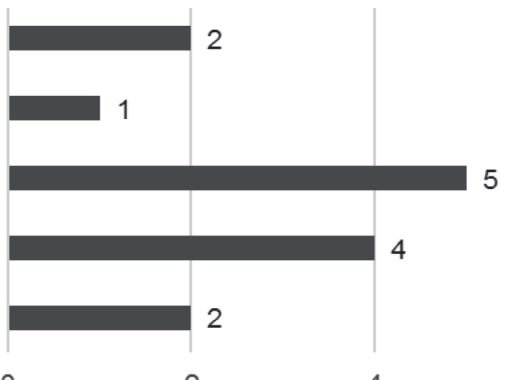

0

2
4

- Number of respondents

Source: own calculation

to increase the revenue of the municipality. Most often, this coefficient is used to differentiate the various parts of the municipality according to infrastructure and attractiveness as it does not have to be set for the whole territory of the municipality at the same level (Fig. 10). An interesting reason is to increase the coefficient as an incentive to shorten the building period, because then the building will be taxed by using the corrective coefficient for buildings, which is lower. On the other hand, municipalities can benefit from a reduction in corrective coefficients for the reason of supporting the new building in the selected location.
Similarly, a different objective is pursued than to increase the revenue of the municipality while reasoning for the modification of corrective coefficients for buildings. This coefficient is used to differentiate the various parts of the municipality according to infrastructure, attractiveness, amenities and access to employment. The reduction of corrective coefficients is also used in parts of the municipalities that are affected by the negative impact of transport or mining activities (see Fig. 11).

The local coefficient was set by 18 respondents and half of them had it already 


\section{Fig. 11: Motivation for modifying corrective coefficients for buildings}

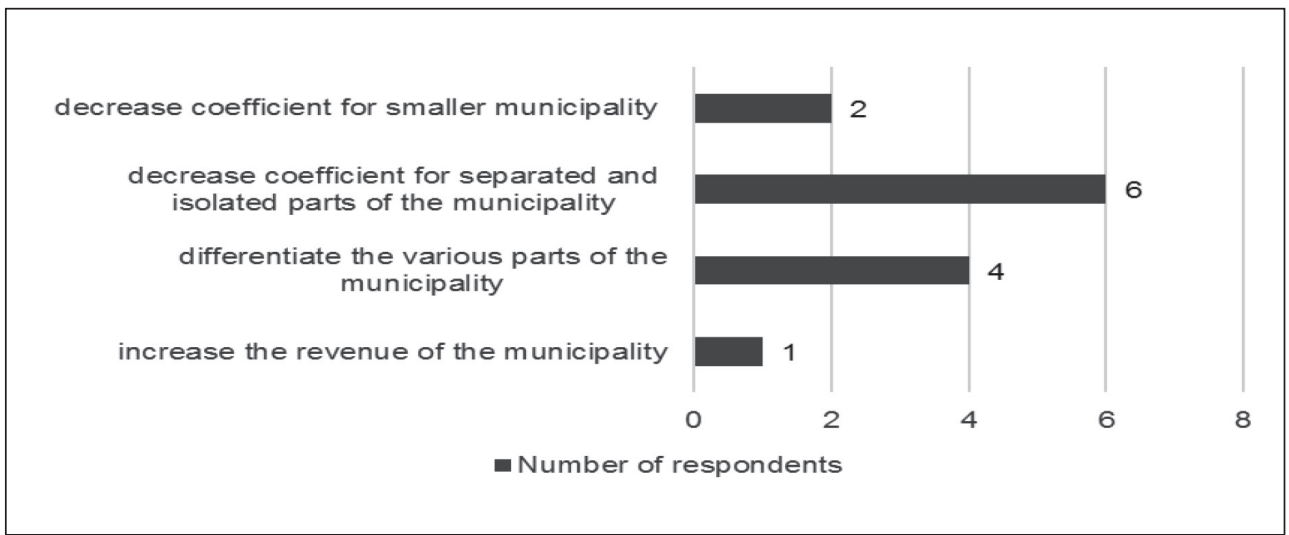

Source: own calculation

introduced in 2009. The prevailing local coefficient rate is above 2 (a total of 12 municipalities), the amount of the coefficient is generally most frequently used also in the Czech Republic. Unlike other coefficients, the most common reason for introducing the local coefficient is generally to increase the revenue in the municipal budget. Or the revenue is used for specific investment needs of municipalities such as sewer construction. The increase in tax yields occurs in municipalities that are industrial and on whose territory large entrepreneurial businesses have their property. As found most municipalities have higher costs associated with the maintenance of the cadastral area, which is mortgaged property owned by business entities. Municipalities also want to motivate firms through coefficients for the better use of property on the territory of the municipality with the aim of securing new jobs, especially for the citizens of the municipality. These are often the buildings of companies that have their headquarters outside the municipality (especially in large cities such as Prague and Brno) and therefore assigned taxes flow into the budgets of other towns.

In the context of municipalities with a high population growth and increased construction, there is also an increase in the costs of installation of utilities, public lighting, radio, and maintenance of local roads, which also encourages municipalities to introduce local coefficients. Municipalities that are recreational areas with sports and recreational facilities also introduce local coefficients for increasing the revenue, and the increased tax is compensated to the citizens of the municipality, for example, by reducing or abolishing certain fees (e.g. waste disposal) and thus the municipality also reduces the administrative burden in connection with the collection of these fees.

Based on questionnaires reasons were also identified why municipalities do not use the possibility of introducing coefficients. One of the reasons, is, for instance, a low number of inhabitants in the municipality, or a small increase in the revenue of the municipality at the expense of the high financial burden on citizens.

\subsection{The Effect of the Municipality Location on Researched Phenomena}

By using the chi-square test it was verified whether the municipality location in the district influenced its decision on assessing or modifying coefficients. A zero hypothesis $\mathrm{H}_{0}$ was set: Determining or modifying coefficients do not depend on the municipality location.

Based on the results in the above table (Tab. 3) we can say that we shall reject the null hypothesis. The decision on introducing or modifying coefficients depends on the municipality localization. There are significant differences between the municipalities, which 
Tab. 3: Verification of the hypothesis $H_{0}$

\begin{tabular}{l|c} 
CHI-SQUARE & 12.6643 \\
\hline alfa & 0.05 \\
\hline df & 5 \\
\hline CHINV & 11.0705 \\
\hline CHIDIST & 0.0267 \\
\hline
\end{tabular}

Source: own calculation

\begin{tabular}{|c|c|c|c|}
\hline \multirow[t]{2}{*}{ Tab. 4: } & \multicolumn{3}{|c|}{$\begin{array}{l}\text { The use of coefficients according to districts in the Moravian-Silesian Region } \\
\text { (in \%) }\end{array}$} \\
\hline & Municipality & Use of coefficients & $\begin{array}{l}\text { Municipalities of lower } 1,000 \\
\text { inhabitants }\end{array}$ \\
\hline \multicolumn{2}{|l|}{ Bruntál } & 28 & 78 \\
\hline \multicolumn{2}{|c|}{ Frýdek-Místek } & 50 & 40 \\
\hline \multicolumn{2}{|c|}{ Karviná } & 47 & 0 \\
\hline \multicolumn{2}{|c|}{ Nový Jičín } & 30 & 48 \\
\hline \multicolumn{2}{|l|}{ Opava } & 30 & 47 \\
\hline \multicolumn{2}{|c|}{ Ostrava-město } & 54 & 31 \\
\hline \multicolumn{2}{|c|}{ Moravian-Silesian Region } & 36 & 49 \\
\hline
\end{tabular}

Source: own calculation

are located in different districts of the MoravianSilesian Region, such as municipalities in Opava, which do not use the option of determining the local coefficient.

As shown in Tab. 4 the percentage of municipalities that use the coefficients in the individual districts is very different. Municipalities on average at $36 \%$ in the Moravian-Silesian Region use the coefficients; municipalities in the districts of Bruntál, Nový Jičín and Opava are below average. Conversely, a higher percentage is the districts of Frýdek-Místek, Karviná and Ostrava-město. There can also be monitored the link between the size of municipalities, as in all three districts using coefficients to a greater extent, larger municipalities of over 1,000 inhabitants predominate.

\section{Conclusion}

Fiscal decentralization in the context of the reallocation of public resources is a complex and multi-faceted process, which fosters social priorities and strategies. Local taxes and especially the tax on immovable property is considered the most apposite municipal tax. However, a number of contentious issues are associated with this tax in the context of valuation, assessment of the tax rate or controversy if the property should be taxed at all, in spite of it, the taxation revenue of the of immovable property fills municipal budgets more or less in all European Union countries.

Municipalities in the Czech Republic have the ability to affect tax revenues on immovable property through coefficients thus being the only assigned tax. As found in the carried out analyses, the possibility of modifying coefficients for increasing the revenue is still underused by municipalities. E.g., the introduction of the local coefficient is still postponed by almost $92 \%$ of the municipalities in the Czech Republic, either due to concerns of inhabitants about raising taxes or as a result of insufficient orientation of the municipal council in the given field.

It was found that the municipal coefficient is most used, whose determination is the simplest and does not burden the residents of the given municipality. The use of modifications of corrective coefficients is low and it is used only by $6.4 \%$ of the municipalities in the Czech Republic, although there are large differences 
between regions. The local coefficient that can be considered the most effective tool by which the municipality as a recipient of tax can significantly increase the tax revenue on immovable property on its territory is used by an average of $8.3 \%$ of municipalities, and municipalities in the Karlovy Vary Region use it most.

The Moravian-Silesian region is among the regions with higher tax revenues on immovable property. It is largely due to its industrial character. Analyses made suggests that even here there is certainly the possibility for increasing municipal budgets through the tax revenue on immovable property by increasing or modifying coefficients.

As the primary research revealed (conducted in the years 2014-2016) motivation to use coefficients to increase tax yields on immovable property is different. They differ mainly in relation to the specific application of the individual coefficients. Differences also result from the structure of buildings and land on the territory of the municipality and the way they are used. Some municipalities introduce coefficients to increase the taxation of buildings for family recreation, while others want to burden buildings for business by a higher tax.

It was found that taxpayers when providing transparency of the use of the revenues do not negatively perceive the higher tax burden, particularly in smaller municipalities. Thus, the principle of subsidiarity is fulfilled, where decision-making and accountability in public affairs, takes place at the lowest level of public administration being closest to citizens. It is therefore in the interest of the municipality to explain to taxpayers what consideration is granted, not only by public lighting infrastructure facilities, protection of property or an increase in property values, but municipalities finance e.g. schools, kindergartens, subsidize public transport (Janoušková \& Sobotovičová, 2016b). This leads to increased political accountability, thanks to the proximity of voters.

Even though tax revenues on immovable property have had a growing trend since 1993, the Czech Republic is still among the countries with the lowest share of taxes in total tax revenues in EU countries. It is mainly due to the structure of the tax base and the assessment of the tax base is subject to criticism, which is not based on property value reflecting inflation. Problems concerning income and expenditure balancing arise in municipalities, as public expenditure is subject to inflation.

This paper was supported by the Ministry of Education, Youth and Sports Czech Republic within the Institutional Support for Long-term Development of a Research Organization in 2017.

\section{References}

Bečica, J. (2014). Municipalities and assigned taxes. Business trends, 4(4), 4-11.

Bird, R. M. (2010). Local Government Finance: Trends and question. In IEB'S World Report on Fiscal Federalism (pp. 10-23). Institut d'Economia de Barcelona.

Bird, R. M. (2011). Subnational taxation in developing countries: a review of the literature. Journal of International Commerce, Economics and Policy, 2(01), 139-161. doi:10.1142/ S1793993311000269.

Birch, J., \& Sunderman, M. (2013). Regression Modeling for Vertical and Horizontal Property Tax Inequity. Journal of Housing Research, 23(1), 89-104.

Bish, R. L., \& Kirk, R. J. (1974). Economic Principles and Urban Economic. Englewood Cliffs, N.J.: Prentice-Hall.

Blöchliger, H., \& Pinero Campos, J. (2011). Tax Competition between Sub-Central Governments. [OECD Working Papers on Fiscal Federalism No. 13]. doi:10.1787/5k97b1120t6ben.

Bryson, P. J. (2010). The Economics of Centralism and Local Autonomy: Fiscal decentralization in the Czech and Slovak Republic. New York: Palgrave Macmillan.

Coombs, C. K., Sarafoglou, N., \& Crosby, W. (2012). Property taxation, capitalization, and the economic implications of raising property taxes. International advances in economic research, 18(2), 151-161. doi:10.1007/s11294012-9349-0.

Czech Statistical Office. (2016). Regionální statistiky. Retrieved February 2, 2016, from http://www.czso.cz/csu/czso/regiony_mesta_ obce_souhrn.

European Commission.

(2015). Commission staff working document country report Czech Republic 2015. Retrieved May 15, 2015, from http://ec.europa.eu/europe2020/ pdf/csr2015/cr2015_czech_cs.pdf.

European Union. (2016). Taxation trends in the European Union. Luxembourg: 
Publications Office of the European Union. doi:10.2778/33696.

Haider-Markel, D. P. (2014). Oxford Handbook of State and Local Government. Oxford University Press (Verlag). Retrieved September 14, 2015, from http:// siteresources.worldbank.org/INTDEBTDEPT/ Resources/468980-1207588563500/48646981207775351512/WPS5450.pdf.

Horne, R., \& Felsenstein, D. (2010). Is property assessment really essential for taxation? Evaluating the performance of an 'Alternative Assessment' method. Land use policy, 27(4), 1181-1189. doi:10.1016/j. landusepol.2010.03.008.

Janoušková, J., \& Sobotovičová, Š. (2016a). Využití koeficientů ke zvýšení výnosů daně z nemovitých věcí v Moravskoslezském kraji. In V. Klímová, \& V. Žítek (Eds.), XIX. mezinárodní kolokvium o regionálních vědách. Sborník příspěvků (pp. 883-890). Brno: Masarykova univerzita.

Janoušková, J., \& Sobotovičová, Š. (2016b). Immovable property tax in the Czech Republic as an instrument of fiscal decentralization. Technological and Economic Development of Economy, 22(6), 767-782. doi:10.3846/202949 13.2016.1236355.

Keith, S., \& McCluskey, W. (2004). Decentralization and Rural Property Taxation. Rome: Food and agriculture organization of the United nations. Retrieved August 22, 2015, from https://books.google. $\mathrm{cz} / \mathrm{books} ? \mathrm{id}=\mathrm{w} 9 \mathrm{IzzcK} 4 \mathrm{~s} 5 \mathrm{Q} \mathrm{C} \&$ printsec $=$ frontcover\&hl=cs\#v=onepage \&q\&f=false.

Marková, H. (2007). Vlastní nebo sdílené daně obcím. In Dny veřejného práva (pp. 1-9). Brno: Masarykova univerzita.

MFCR. (2016). Fiscal Data for the Czech Republic. Retrieved May 5, 2016, from http:// www.mfcr.cz/cs/verejny-sektor/hospodareni/ uzemni-rozpocty/statni-zaverecny-ucetuzemnich-rozpoctu/2014/szu-uzemnichrozpoctu-2014-21891.

Mrkývka, P. (2003). Podatek od nieruchomości w Republice Czeskiej. In Europejskie systémy opodatkowania nieruchomości - praca zbiorowa pod redakcją prof. Leonarda Etela (pp. 117-118). Warszawa: Kancelaria Sejmu.

OECD. (2010). Economic Surveys Czech Republic. Retrieved October 11, 2015, from http://www.mfcr.cz/cps/rde/xbcr/mfcr/CZE_2010 PB_ENG.pdf.

OECD. (2011). Economic Surveys Czech
Republic. Retrieved October 11, 2015, from http://www.mfcr.cz/cps/rde/xbcr/mfcr/ CZE_2011PB_ENG.pdf.

OECD. (2016). Fiscal Decentralisation Database. Retrieved October 10, 2016, from http://www.oecd.org/tax/federalism/oecdfis caldecentralisationdatabase.htm\#A_Title.

Presbitero, A. F., Sacchi, A., \& Zazzaro, A. (2014). Property tax and fiscal discipline in OECD countries. Economics Letters, 124(3), 428-433. doi:10.1016/j.econlet.2014.06.027.

Ramík, J., \& Perzina, R. (2014). Microsoft Excel as a Tool for Solving Multicriteria Decision Problems. Procedia Computer Science, 35, 1455-1463. doi:10.1016/j.procs.2014.08.206.

Roubínek, P., Kladivo, P., Halás, M., Koutský, J., \& Opravil, Z. (2015). Changes in the financing of municipalities and local governments of selected cities: possible effects on disintegration processes and municipal policy. E\&M Ekonomie a Management, 18(1), 134-150. doi:10.15240/tul/001/2015-1-011.

Sedmihradská, L. (2015). Municipal budget outlooks: Are they really utilised? Acta academica karviniensia, 2015(4), 80-88.

Smith, S. M., Bryson, P. J., \& Cornia, G. C. (2011). The view from city hall: Local perceptions of intergovernmental fiscal relations in the Czech Republic. Communist and Post-Communist Studies, 44(1), 99-110. doi:10.1016/j.postcomstud.2011.01.009.

Tanzi, V. (1991). Public Finance in Developing Countries. Aldershot: Edward Elgar Publishing.

Tax administration. (2015). The annual reports of the Czech tax administration 19992014. Retrieved May 5, 2015, from http://www. financnisprava.cz/.

Tiebout, C. M. (1956). A Pure Theory of Local Expenditures. Journal of Political Economy, 64(5), 416-424. doi:10.1086/257839.

doc. Ing. Jana Janoušková, Ph.D.

Silesian University in Opava School of Business Administration in Karvina Department of Finance and Accounting janouskova@opf.slu.cz

Ing. Šárka Sobotovičová, Ph.D. Silesian University in Opava School of Business Administration in Karvina Department of Finance and Accounting sobotovicova@opf.slu.cz 


\section{Abstract}

\section{PROPERTY TAX IN THE REGIONS OF THE CZECH REPUBLIC Jana Janoušková, Šárka Sobotovičová}

Fiscal decentralization in the context of the reallocation of public resources is a complex and multifaceted process, which fosters social priorities and strategies. The main objective is to increase the self-reliance and self-sufficiency of municipalities related to allocation efficiency and possible adjustment to the local conditions. The municipalities in the Czech Republic have the possibility to affect the tax revenue on immovable property by means of the coefficients being thus the only assigned tax. The aim of the paper is to determine the use of legislative tools to increase the tax revenue on immovable property in the regions of the Czech Republic. Access of municipalities to the increase in the tax revenues on immovable property is then studied through three coefficients within the Moravian-Silesian Region. Examples of good practice in motivating municipalities to implement or modify selected coefficients leading to an increase in municipal budgets are examined. The article also performs a description of the development of the tax on immovable property in the Czech Republic, on the basis of the time series of tax imposed as a follow-up to the legislative changes. Methodically the research relies on the evaluation of secondary statistical data of the Czech Statistical Office and Financial Administration of the Czech Republic, and the primary research that was implemented in 2016 focuses on the application of the coefficients by municipalities of the Moravian-Silesian Region. This research closely follows up on the research of the use of local coefficients, which was carried out in 2014 and 2015.

Key Words: Fiscal decentralization, tax autonomy, immovable property tax, regions, MoravianSilesian Region.

JEL Classification: $H 70, H 71$.

DOI: 10.15240/tul/001/2017-4-009 